1955. 1 seen in WINNIPEG, Man., Oct. 23-25, by A. W. Sellers, feeding on crabapples. (Chickadee Notes $\# 42$, cited by $\mathrm{H}$. Hosford).

1960. 1 seen on Apr. 23 in CARLOS AVERY REFUGE, Anoka Co., Minn., by D. Pearson.

1960. 1 seen in HENNEPIN CO., Minn., May 1, by Mrs. A. C. MacInnes; 1 seen same area, May 2, by Mrs. Donald Barr; 1 seen same area, May 3, by R. B. Janssen (possibly same bird); 1 seen SCOTT CO., Minn., May 6, by Sophia Harms; 1 seen RICE CO., Minn., May 10-13, by Mrs. R. A. Houston. (The Flicker, Sept., 1960 , cited by R. Huber).

1960. 1 seen May 27 south side of WINNIPEG, Man., flycatching, by H. Hosford. (Pers. corr. H. Hosford).

1960. 1 seen in RAMSEY CO., Minn., July 1, by Mrs. R. Leach. (The Flicker, Sept. 1960, cited by R. Huber).

1960. 1 remained at feeder of Dr. W. J. Jeffries, HOPKINS, Minn., from early Nov. to March 1, 1961. (The Flicker, June, 1961, cited by $\mathrm{R}$. Huber).

1961. 1 seen by V. Heig, May 3, at ST. PAUL, Minn., remained a week. (The Flicker, June, 1962, cited by Huber).

\section{ADDITIONAL FALL RECORDS OF THE YELLOW RAIL}

\section{by Gary Anweiler, Melville}

On October 5; :1964, while I was hunting snipe with Dr. R: W. Nero in a grassy spring-fed bog in the Qu'Appelle Valley 10 miles west of Lumsden, Dr. Nero's dog flushed a Yellow Rail (Coturnicops noveboracensis) which I collected. It proved to be an adult female and has been prepared as a specimen for the collections of the University of Saskatchewan, Regina Campus. Common Snipe were abundant in the bog; at least 50 were present. A few Soras were also flushed.

There are two other local fall specimens for the Yellow Rail. Both were TV tower casualties, and therefore probably migrants, found by Fred W. Lahrman. One, found at Regina on October 7, 1962 (Blue Jay; 20:152) was a female, and the specimen appears to be in adult plumage. This record was
1962. 1 seen at ROSEMOUNT, Minn., May 19, by $\mathrm{R}$. Glassel. (The Flicker, June, 1962, cited by R. Huber).

1962. 1 adult banded May 24 at ST. PAUL, Minn., by Mrs. R. Leach. (The Flicker, Sept., 1962, cited by R. Huber).

1963. 1 seen at TWO HARBORS, Minn., May 11-23, by Ruth Kuchta. (The Flicker, June, 1963, cited by $R$. Huber).

1963. 1 seen at WEST NEWTON, Minn., May 15, by Grace Gordon. (The Flicker, June, 1963, cited by $\mathrm{R}$. Huber).

1963. 1 seen at NIOBRARA REFUGE, Nebr., about May 20, by Dr. A. E. Allin. (The Flicker, June, 1963, cited by R. Huber).

1963. 1 seen at ST. PAUL, Minn., Nov. 7, by Mrs. R. Leach. (The Flicker, Dec., 1963, cited by R. Huber).

1964. 1 seen at ANOKA, Minn., April 19 , by R. Huber. (The Loon, June, 1964, cited by R. Huber).

1964. 1 seen at DULUTH, Minn., May 9-10, by Janet C. Green. (The Loon, June, 1964, cited by $\mathrm{R}$. Huber).

1964. I seen at WINNIPEG, Man., May 27-June 4, by David Hatch, Harold Hosford et al (Pers. corr. H. Hosford). discussed, together with a brief summary of the status of this species in Saskatchewan, by Margaret Belcher (Blue Jay, 20:153). A second Yellow Rail, found at Lumsden on August 21, 1964, was also a fomale; judging by its plumage it is an immature bird.

\section{CHRISTMAS BIRD COUNT DATES}

\section{Tuesday, December 22, 1964 through \\ Sunday, January 3, 1965}

List the numbers of each species seen on the ONE BEST DAY. In addition, list any other species seen during the count period, giving number of individuals and dates seen.

Send reports as soon as possible after January 3 to Mrs. Stuart Houston, 863 University Drive, Saskatoon. 